\title{
KARAKTERISASI MORFOLOGI KETURUNAN PERTAMA IKAN NILA (Oreochromis niloticus) GET DAN GIFT BERDASARKAN METODE TRUSS MORPHOMETRICS
}

\author{
Otong Zenal Arifin*) dan Titin Kurniasih*)
}

\begin{abstract}
ABSTRAK
Penelitian yang bertujuan untuk mendapatkan informasi karakter morfometrik dan variasi morfologi ikan nila (Oreochromis niloticus) keturunan pertama populasi GET dan GIFT telah dilaksanakan di Balai Riset Perikanan Budidaya Air Tawar, Bogor. Tujuh famili nila GET dan dua famili nila GIFT, dengan jumlah sampel masing-masing 30 ekor (15 jantan dan 15 betina) dievaluasi menggunakan metode truss morfometrik pada empat bagian tubuhnya. Dari 21 karakter truss yang diukur, terdapat delapan karakter yang dapat dipakai untuk membedakan kesembilan famili yang dievaluasi. Nilai sharing komponen dalam famili tertinggi adalah pada famili GET $18 \mathrm{C}(86,7)$ dan terendah pada famili $18 \mathrm{~A}(43,3)$ serta $09 \mathrm{C}(43,3)$, sedangkan nilai sharing komponen antar famili tertinggi diperoleh antara famili GET 18A dengan famili GIFT 10 dengan nilai 40,0. Berdasarkan kluster dendrogram jarak genetik dengan tingkat kemiripan 70\% didapatkan tiga kelompok yang berbeda secara morfologi. Kelompok 3 terutama famili GET 09C adalah famili tersendiri dan terpisah dari famili lainnya. Jarak genetik terbesar adalah antara famili GET 09C dengan famili GET 18C dengan nilai 0,026; sedangkan jarak genetik terkecil terdapat di antara famili GIFT 10 dengan famili GET 18A dengan nilai 0,001 .
\end{abstract}

ABSTRACT: Morphological characterization of GET and GIFT tilapia F1 generation based on truss morphometrics variability. By: Otong Zenal Arifin and Titin Kurniasih

Research aimed at elucidating morphological character and variation between GET and GIFT nile tilapia (Oreochromis niloticus) have been conducted at Research Institute for Freshwater Aquaculture, Bogor. Seven GET and two GIFT nile tilapia families, which consisted of 30 individu in each family (15 males and 15 females), were measured using truss morphometrics methods on four main part of their body. There were eight morphometrics characters can be used to differentiate the nine families, from 21 characters used. The highest within family sharing component was founded at GET $18 \mathrm{C}$ (86.7), whereas the lowest one was at $18 \mathrm{~A} \mathrm{(43.3)} \mathrm{and} \mathrm{09C} \mathrm{(43.3).} \mathrm{The} \mathrm{highest}$ between family sharing component was between GET $18 A$ and GIFT 10 (40.0). Based on genetic distance cluster dendrogram (with degree of similarity 70\%), there were three separated groups has been classified. Group $3^{\text {rd }}$, especially GET O9C was far isolated from other families. The highest genetic distance was between GET O9C and GET 18C (0.026), while the lowest one was between GIFT 10 and GET 18A (0.001).

KEYWORDS: nile tilapia, GET and GIFT, truss morphometrics, variability

\footnotetext{
*) Peneliti pada Balai Riset Perikanan Budidaya Air Tawar, Bogor
} 


\section{PENDAHULUAN}

Ikan nila (Oreochromis niloticus) merupakan salah satu ikan introduksi yang sudah cukup lama dikenal oleh masyarakat Indonesia. Pertama kali ikan nila didatangkan ke Indonesia dari Taiwan pada tahun 1969, kemudian nila merah NIFI tahun 1981 dan nila hitam chitralada tahun 1984. Balai Penelitian Perikanan Air Tawar mengintroduksikan ikan nila GIFT (Genetic Improvement of Farmed Tilapia) generasi 3 dan generasi 6 pada tahun 1995 dan 1997, dan selanjutnya tahun 2002 Pemerintah Propinsi Jawa Barat melalui Balai Pengembangan Benih Ikan (BPBI) Wanayasa bekerja sama dengan BFAR (Bureau of Fisheries and Aquactic Resources) Philipina mendatangkan famili pembentuk ikan nila GET (Genetically Enhanced Tilapia).

Perkembangan budi daya nila yang pesat disertai kegiatan pembenihan yang tidak terkontrol mengakibatkan kualitas genetik nila mengalami penurunan yang ditandai dengan sifat-sifat seperti pertumbuhan lambat, tingkat kematian tinggi, dan matang kelamin usia dini. Salah satu penyebabnya adalah karena banyak terjadi silang dalam (inbreeding) pada usaha pembenihannya. Untuk mengatasi masalah ini perlu dilakukan perbaikan kualitas genetik ikan nila (Imron et al., 2000).

Untuk melakukan program perbaikan genetik, salah satu hal mendasar yang harus terlebih dahulu diketahui adalah tingkat keragaman dan potensi keragaman genetik. Keragaman genetik suatu populasi sangat penting artinya karena faktor inilah yang mempengaruhi respon populasi terhadap seleksi, baik seleksi alam maupun seleksi buatan yang dilakukan oleh manusia (Imron, 1997).

Pengukuran keragaman genetik ikan dapat dilakukan berdasarkan karakter fenotif (meristik, morfometrik, fluktuasi asimetri) dan karakter genotifnya (isozyme, DNA mitokondria, DNA mikrosatelit, dan lain-lain). Walaupun teknik pengukuran keragaman genetik telah maju, tetapi pengukuran keragaman genetik dengan metode pengukuran morfologi tetap dibutuhkan karena sifat-sifatnya dapat langsung dilihat, mudah dilakukan, tanpa fasilitas yang rumit, serta lebih murah biayanya dibandingkan dengan pengukuran karakter genotifnya. Menurut Li Sifa (1997), pengukuran morfologi dengan metode truss morphometrics pada ikan nila memberikan hasil yang lebih akurat dibandingkan hanya dengan pengukuran meristik dan morfometrik biasa. Hal ini disebabkan rendahnya perbedaan genetik secara intraspesifik pada ikan nila pada umumnya. Selanjutnya dikatakan bahwa dengan metode pengukuran truss morphometrics, lima strain ikan nila (nila "78", nila "88", GIFT, EGYPT, dan AMERICA) memperlihatkan perbedaan yang nyata, dibandingkan dengan metode pengukuran biasa. Demikian juga menurut Imron et al. (2000), metode pengukuran karakter morfologi menggunakan truss network memberikan gambaran bentuk tubuh yang menyeluruh dan menghasilkan karakterisasi geometrik bentuk tubuh ikan secara lebih sistematik sehingga akan meningkatkan kemampuan dalam mengidentifikasi perbedaan bentuk tubuh ikan.

Penelitian ini bertujuan untuk mengidentifikasi dan mengkarakterisasi beberapa populasi famili pembentuk ikan nila $(O$. niloticus) GIFT dan GET, berdasarkan karakter fenotif dengan menggunakan metode truss morphometrics.

\section{BAHAN DAN METODE}

Ikan uji yang digunakan merupakan keturunan pertama (F1) 7 famili ikan nila GET dan 2 famili ikan nila GIFT. Pengukuran dilakukan pada ikan yang berukuran bobot $45,3 \pm 62,75 \mathrm{~g}$ dan panjang standar 108,0 \pm $5,71 \mathrm{~mm}$, dengan masing-masing famili diwakili sebanyak 30 ekor, terdiri atas 15 ekor jantan dan 15 ekor betina (Tabel 1). Pengukuran ikan dilakukan dengan metode truss morphometric yang meliputi: pengukuran jarak titik-titik tanda yang dibuat pada kerangka tubuh (Gambar 1)

Dalam penelitian ini parameter yang diuji adalah jarak genetik, keeratan korelasi, serta penyebaran karakter antar famili ikan yang diamati. Data morfometrik baik yang berasal dari metode pengukur konvensional maupun truss, dianalisis menggunakan program SPSS. Jarak genetik dihitung melalui analisis komponen utama (PCA), keeratan korelasi dengan analisis diskriminan, dan untuk melihat penyebaran karakter dilakukan dengan analisis canonical (Karson, 1982).

Analisis komponen utama (PCA) merupakan metode statistik deskriptif yang bertujuan untuk mempresentasikan sebagian besar informasi yang terdapat dalam suatu matriks 
Tabel 1. Famili ikan uji, silsilah induk, dan jumlah ikan nila uji

Table 1. The family name, broodstock source and the number of experimental fish

\begin{tabular}{|c|c|c|}
\hline $\begin{array}{l}\text { Famili } \\
\text { Families }\end{array}$ & $\begin{array}{l}\text { Sumber induk } \\
\text { Broodst ock source }\end{array}$ & $\begin{array}{c}\text { Jumlah } \\
\text { sampel (ekor) } \\
\text { Sample } \\
\text { number (ind.) }\end{array}$ \\
\hline GET 18A & $\begin{array}{c}\text { F18XF18 (BFAR B } \times \text { Kenya) } \times(\text { Kenya } \times \text { BFAR B }) X \\
\text { (BFAR B } \times \text { Kenya) } \times(\text { Kenya } \times \text { BFAR B })\end{array}$ & 30 \\
\hline GET $18 \mathrm{C}$ & $\begin{array}{c}\text { F1 8XF22 (BFAR B } \times \text { Kenya) } \times(\text { Kenya } \times \text { BFAR B) X } \\
(\text { Kenya } \times \text { BFAR B }) \times(\text { BFAR A } \times \text { BFAR A })\end{array}$ & 30 \\
\hline GET 18B & $\begin{array}{c}\text { F22XF1 } 8 \text { (Kenya } \times \text { BFAR B }) \times(\text { BFAR A } \times \text { BFAR A) X } \\
(\text { BFAR B } \times \text { Kenya) } \times(\text { Kenya } \times \text { BFAR B })\end{array}$ & 30 \\
\hline GET 09B & $\begin{array}{l}\text { F9XF9 }(\text { BFAR A } \times \text { BFAR A) } \times(\text { BFAR B } \times \text { Kenya) } X \\
(\text { BFAR A } \times \text { BFAR A) } \times(\text { BFAR B } \times \text { Kenya })\end{array}$ & 30 \\
\hline GET 09C & $\begin{array}{c}(\text { BFAR A } \times \text { BFAR A) } \times(\text { BFAR B } \times \text { Kenya }) X \\
(\text { BFAR B } \times \text { BFAR B }) X(\text { BFAR A } \times \text { BFAR A }\end{array}$ & 30 \\
\hline GET 04B & $\begin{array}{c}\text { F4XF1 } 8(\text { BFAR B } \times \text { BFAR B) } X(\text { Keny a } \times \text { BFAR B }) X \\
(\text { BFAR B } \times \text { Kenya }) \times(\text { Kenya } \times \text { BFAR B })\end{array}$ & 30 \\
\hline GET 23 & $\begin{array}{l}\text { F23XF23 (Egypt } \times \text { Egypt) } \times(\text { BFAR A } \times \text { BFAR A) X } \\
\text { F23XF23 (Egypt } \times \text { Egypt }) \times(\text { BFAR A } \times \text { BFAR A) }\end{array}$ & 30 \\
\hline GIFT 04 & Tidak ada data (No data) & 30 \\
\hline GIFT 10 & Tidak ada data (No data) & 30 \\
\hline
\end{tabular}

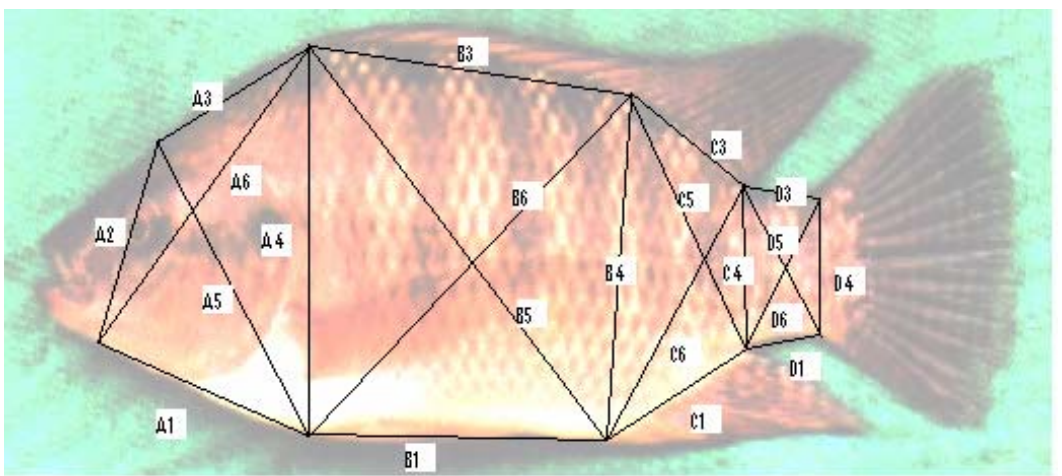

Gambar 1. Titik truss morfologi ikan nila berdasarkan Blezinsky \& Doyle (1988)

Figure 1. Location of landmark point on the body outline for gathering truss morphometrics data according to Blezinsky \& Doyle (1988)

data kedalam bentuk grafik. Pada prinsipnya analisis ini menggunakan pengukuran jarak Euclidean. Jarak Euclidean diperoleh berdasarkan rumus dari Nei \& Tajima (1981):

$$
D^{2}(i / j)=(X i-X j){ }^{\prime} C^{-1}(X i-X j)
$$

di mana:

$D^{2}(i / j)=$ Nilai statistik mahalanobis sebagai ukuran jarak kuadrat genetik antar dua populasi (antara populasi i terhadap populasi j)

$C^{-1}=$ Kebalikan matrik gabungan ragam peragam antar peubah

$X i=$ Vektor nilai rataan pengamatan dari populasi i pada masing-masing peubah

$x_{j}=$ Vektor nilai rataan pengamatan dari populasi j pada masing-masing peubah 


\section{HASIL DAN BAHASAN}

Sebaran karakter morfometrik individu antara famili ikan uji menunjukkan hubungan kekerabatan famili ikan nila tersebut cukup erat, kecuali pada famili GET 09C. Hal ini ditunjukkan dengan adanya daerah himpitan antara famili yang satu dengan famili lainnya. Karakter morfometrik famili GET 09C terpisah dan mengumpul pada sebelah bawah garis aksis $Y$ dan sebelah kiri garis aksis $X$, sedangkan famili GET 09B, GET 23, GET 18 A, GET 18B, GIFT 10, GET 18C, GET 04B, dan GIFT 04 mengumpul dan bersinggungan pada garis nol aksis $X$ dan aksis Y (Gambar 2).

Berdasarkan hasil analisis diskriminan menunjukkan bahwa hubungan kekerabatan antara 9 famili ikan nila yang diteliti (kecuali pada famili GET 09C), cukup dekat yang ditunjukkan dengan adanya daerah himpitan antara famili yang satu dengan yang lainnya. Kedekatan masing-masing famili menandakan antara famili-famili tersebut mempunyai kesamaan secara genetik. Diduga hal ini disebabkan karena famili-famili yang digunakan berasal dari induk yang mempunyai silsilah genetik cukup dekat. Hal ini juga membuktikan bahwa 9 famili ikan nila yang diteliti, baik nila GET maupun nila GIFT masih merupakan satu spesies yaitu Oreochromis niloticus.
Kedekatan hubungan kekerabatan antara famili ikan uji juga dapat disebabkan oleh karena adanya kesamaan sumber genetik pembentuknya. Seperti diketahui, ikan nila GIFT merupakan ikan hasil seleksi secara buatan yang awalnya berasal dari populasi 8 negara yang berbeda yaitu berasal dari Kenya, Mesir, Ghana, Senegal, Israel, Singapura, Thailand, dan Taiwan (Vellasco et al., 1996), sedangkan ikan nila GET merupakan hasil seleksi lebih lanjut antara ikan nila GIFT yang telah ada dengan penambahan kembali unsur populasi awalnya, yaitu populasi Kenya dan populasi Mesir.

Keeratan semua komponen antar 9 famili ikan nila yang diamati lebih nyata dengan menggunakan sharing component atau dengan kata lain indeks kesamaan (index of similarity) antar famili dilakukan dengan menggunakan hasil analisis diskriminan berdasarkan kesamaan ukuran tubuh tertentu (Suparyanto et al., 1999) (Tabel 2).

Nilai indeks kesamaan tertinggi dalam populasi diperoleh pada famili GET $18 \mathrm{C}(86,7 \%)$ dan terendah pada famili GET $18 \mathrm{~A}$ dan GET 09C $(43,3 \%)$. Sedangkan nilai indeks kesamaan tertinggi antar populasi diperoleh antara famili GET 18A dengan GIFT 10 (40\%). Suparyanto et al. (1999) mengemukakan bahwa nilai

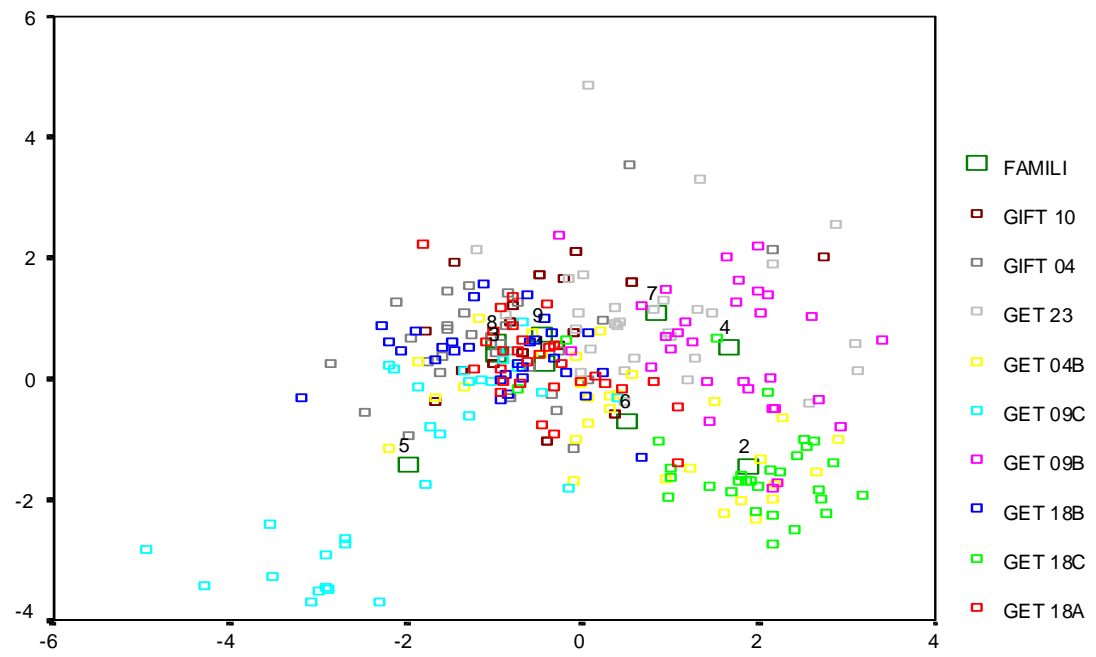

Gambar 2. Sebaran karakter morfometrik sembilan famili ikan nila betina dan jantan berdasarkan hasil analisis diskriminan

Figure 2. Distribution of truss morphometrics character of nine families of nile tilapia based on discriminant analysis 
Tabel 2. Nilai sharing component dalam dan antar sembilan famili ikan nila betina dan jantan (\%)

Table 2. Index of similarity within and between nine families of male and female tilapia

\begin{tabular}{lrrrrrrrrrr}
\hline $\begin{array}{c}\text { Famili } \\
\text { Families }\end{array}$ & $\begin{array}{c}\text { GET } \\
\text { 18A }\end{array}$ & $\begin{array}{c}\text { GET } \\
\text { 18C }\end{array}$ & $\begin{array}{c}\text { GET } \\
\text { 18B }\end{array}$ & $\begin{array}{c}\text { GET } \\
\text { 09B }\end{array}$ & $\begin{array}{c}\text { GET } \\
\text { 09C }\end{array}$ & $\begin{array}{c}\text { GET } \\
\text { 04B }\end{array}$ & $\begin{array}{c}\text { GET } \\
\text { 23 }\end{array}$ & $\begin{array}{r}\text { GIFT } \\
\text { 04 }\end{array}$ & $\begin{array}{c}\text { GIFT } \\
\text { 10 }\end{array}$ & $\begin{array}{c}\text { Jumlah } \\
\text { Total }\end{array}$ \\
\hline GET 18A & 43.3 & 3.3 & 13.3 & 0.0 & 0.0 & 10.0 & 0.0 & 3.3 & 26.7 & 100 \\
GET 18C & 3.3 & 86.7 & 3.3 & 3.3 & 0.0 & 0.0 & 3.3 & 0.0 & 0.0 & 100 \\
GET 18B & 0.0 & 0.0 & 83.3 & 0.0 & 0.0 & 0.0 & 0.0 & 3.3 & 13.3 & 100 \\
GET 09B & 0.0 & 3.3 & 0.0 & 70.0 & 0.0 & 10.0 & 16.7 & 0.0 & 0.0 & 100 \\
GET 09C & 6.7 & 0.0 & 26.7 & 3.3 & 43.3 & 6.7 & 0.0 & 10.0 & 3.3 & 100 \\
GET 04B & 3.3 & 23.3 & 0.0 & 3.3 & 3.3 & 53.3 & 0.0 & 10.0 & 3.3 & 100 \\
GET 23 & 0.0 & 0.0 & 3.3 & 16.7 & 0.0 & 3.3 & 70.0 & 6.7 & 0.0 & 100 \\
GIFT 04 & 6.7 & 0.0 & 0.0 & 3.3 & 0.0 & 6.7 & 0.0 & 76.7 & 6.7 & 100 \\
GIFT 10 & 40.0 & 0.0 & 0.0 & 3.3 & 0.0 & 6.7 & 0.0 & 0.0 & 50.0 & 100 \\
\hline
\end{tabular}

kesamaan ukuran tubuh memberikan penjelasan adanya percampuran yang terukur antara populasi satu dengan populasi lainnya.

Dari 21 karakter yang diukur, karakter yang paling menentukan untuk membedakan morfologi pada ikan jantan adalah karakter D1, D5, B4, dan D4, dengan korelasi positif dan A2, A3, C6, dan D3 untuk korelasi negatif. Nilai korelasi positif tertinggi diperoleh antara D1 dengan D5 $(0,598)$, dan korelasi positif terendah terdapat antara B4 dengan D4 $(0,002)$. Nilai korelasi negatif tertinggi terdapat di antara A2 dengan $A 3(-0,3)$, dan korelasi negatif terendah antara $\mathrm{C} 6$ dengan D3 dengan nilai korelasi -0,005 (Tabel 3).

Karakter yang paling menentukan untuk membedakan morfologi ikan nila betina adalah karakter dengan korelasi positif yaitu D1, D6, dan C4, sedangkan untuk korelasi negatif yaitu C1, D1, A3, dan A4. Nilai korelasi positif tertinggi diperoleh antara D1 dengan D6 dengan nilai 0,679 dan nilai korelasi positif terendah antara A4 dengan C4 dengan nilai 0,005 ; sedangkan nilai korelasi negatif tertinggi adalah antara $\mathrm{C} 1$ dengan $\mathrm{D} 1$ dengan nilai -0,246 dan korelasi negatif terendah antara A3 dengan A4 dengan nilai -0,005 (Tabel 4).

Dari 21 karakter terukur yang diuji dalam penelitian ini, terdapat 8 karakter yang dapat dipakai dalam membedakan 9 famili ikan nila tersebut (baik jantan maupun betina) antara lain yaitu B4, C5, A6, C3, A2, A3, B1, dan C6. Nilai korelasi positif tertinggi diperoleh antara B4 dengan $\mathrm{C} 5(0,666)$ dan terendah antara A6 dengan C3 $(0,001)$, sedangkan untuk nilai korelasi negatif tertinggi diperoleh antara A2 dengan $(-0,266)$, dan nilai korelasi negatif terendah antara B 1 dengan $\mathrm{C} 6$ dengan nilai 0,004 (Tabel 5).

Dari 21 karakter, hanya ada 8 karakter yang paling menentukan untuk membedakan morfologi ikan nila dari 9 famili yaitu pada karakter D1 (jarak titik akhir sirip anal-jarak titik awal sirip ekor bawah), D5 (jarak titik akhir sirip punggung lunak-jarak titik awal sirip ekor bawah), B4 (jarak titik awal sirip punggung lunak-jarak titik awal sirip anal), D4 (jarak titik awal sirip ekor atas-jarak titik awal sirip ekor bawah) untuk kategori karakter dengan korelasi positif, dan karakter A2 (jarak titik bawah mulutjarak titik atas mata), A3 (jarak titik atas matajarak titik awal sirip punggung keras), C6 (jarak titik akhir sirip punggung lunak-jarak titik awal sirip anal), dan D3 (jarak titik akhir sirip punggung lunak-jarak titik awal sirip ekor atas) untuk karakter berkorelasi negatif. Hal ini menunjukkan bahwa meskipun mempunyai kesamaan secara genetik, namun masih memiliki perbedaan dalam karakter morfometrik yang diuji. Korelasi positif menurut Rahmawati (1999), menunjukkan adanya karakter yang berhubungan erat atau suatu karakter bergantung pada karakter yang lain (nila korelasi lebih dari 50\%). Lebih lanjut, Brojo (1999) menyatakan bahwa keeratan korelasi positif maupun negatif dapat menunjukkan karakter tersebut dapat diwakili oleh salah satu karakter yang berkorelasi tinggi.

Pada ikan jantan dari 21 karakter yang diukur, karakter yang paling menentukan untuk membedakan morfologi adalah karakter 


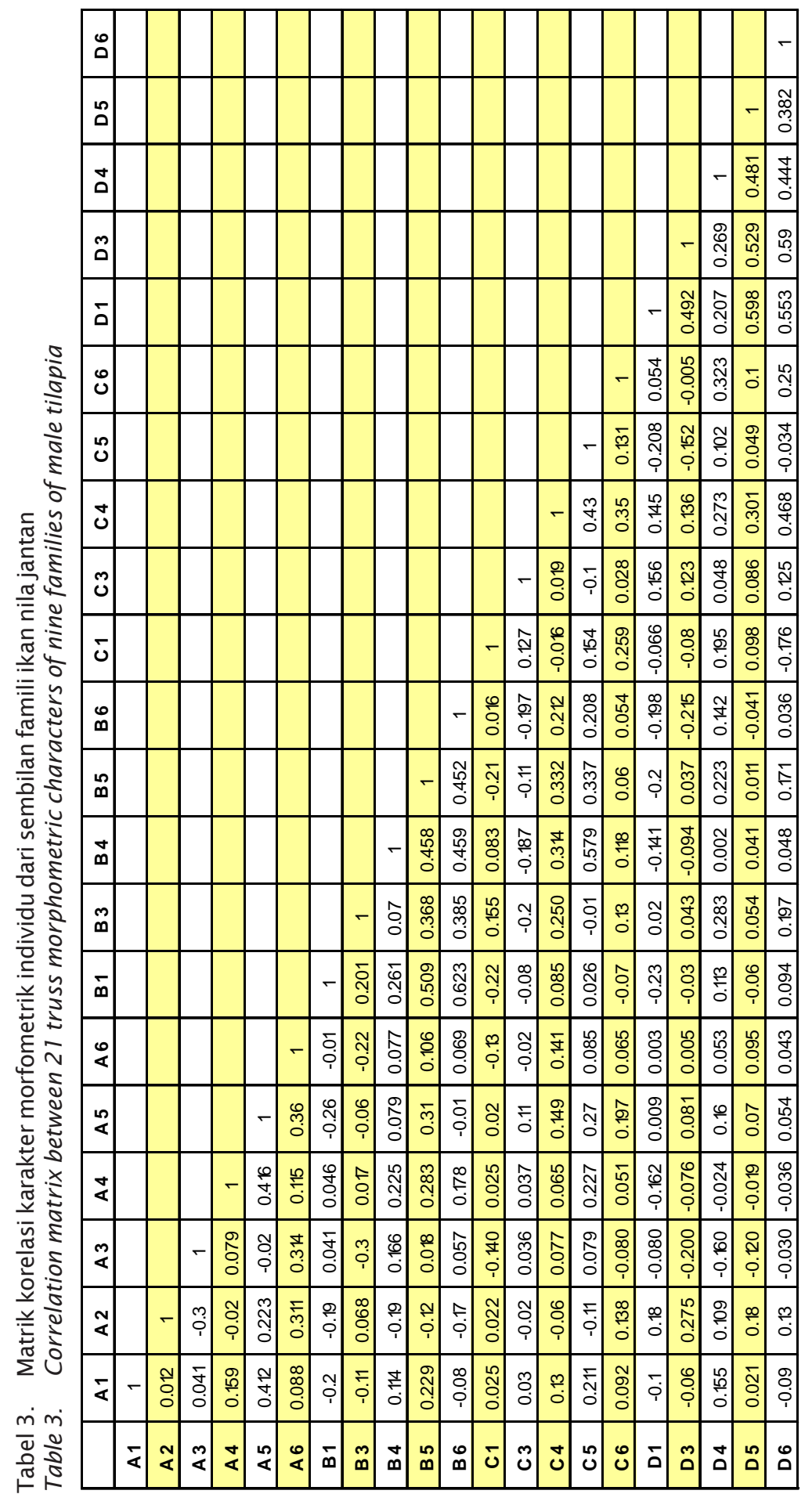




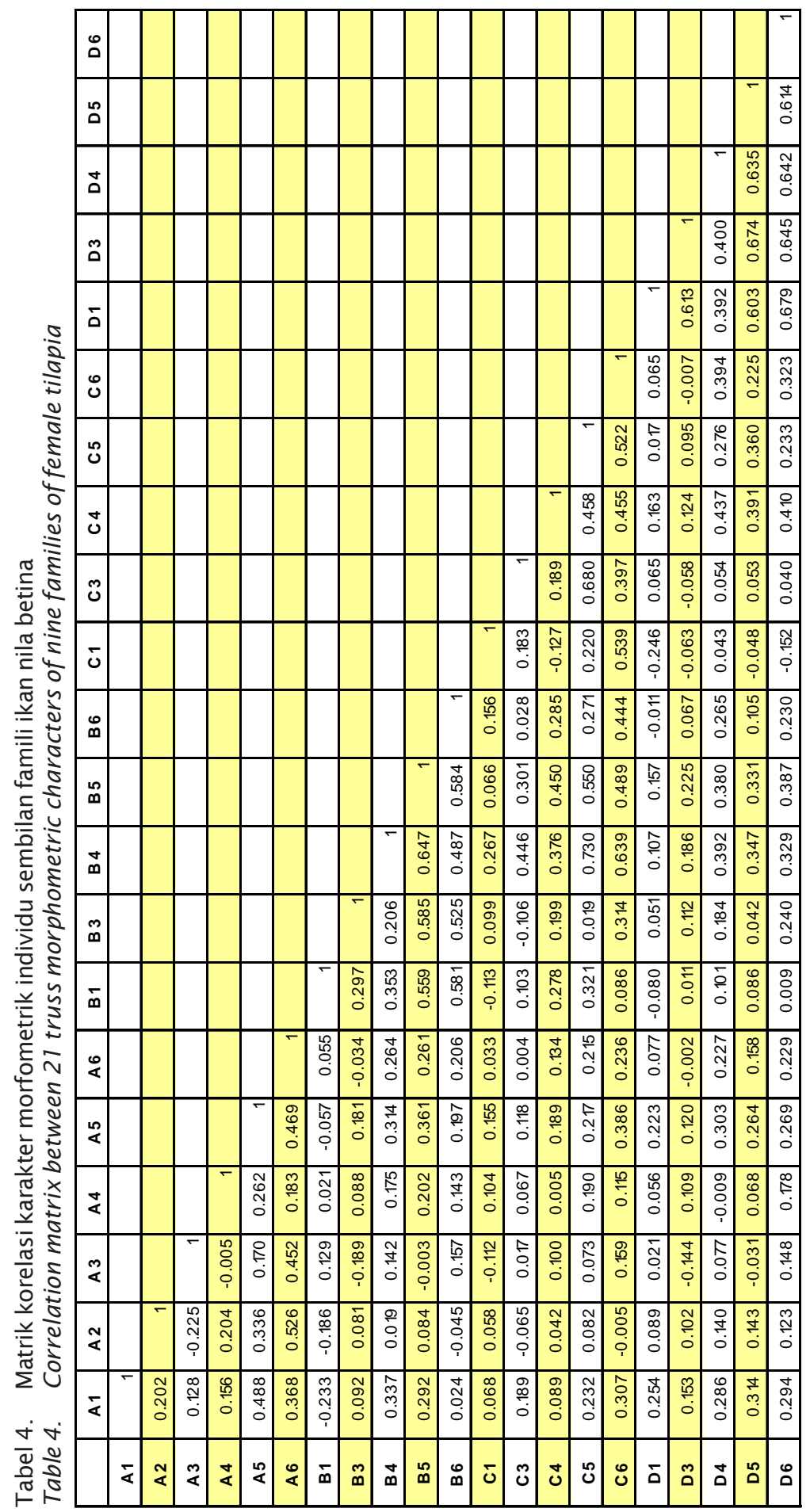




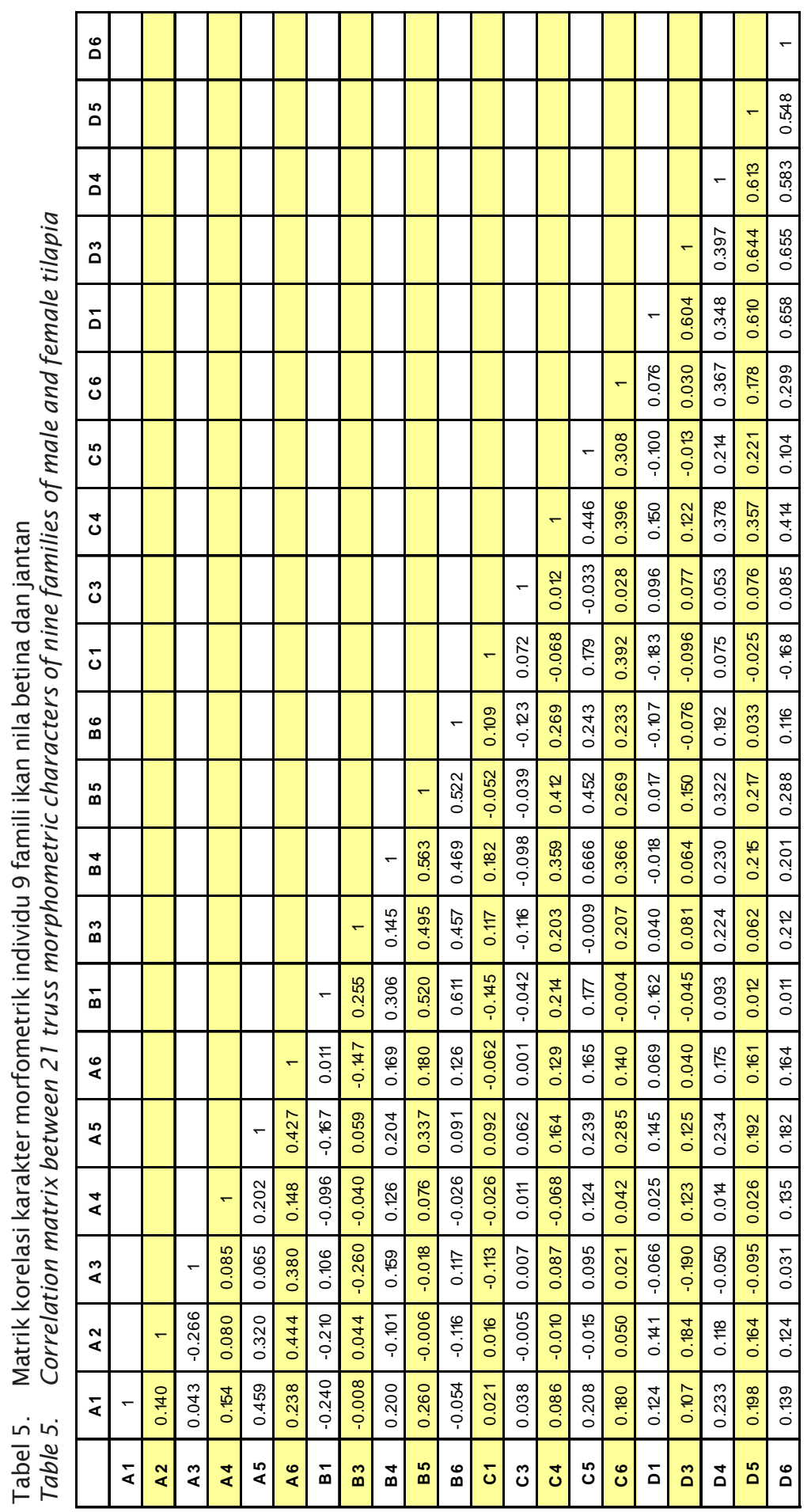


dengan korelasi positif yaitu D1, D5, B4, dan D4; untuk korelasi negatif yaitu A2, A3, C6, dan D3. Sedangkan pada ikan betina karakter yang paling menentukan untuk membedakan morfologi adalah karakter dengan korelasi positif yaitu D1, D6, dan C4, sedangkan untuk korelasi negatif yaitu pada C1, D1, A3, dan A4. Terdapat perbedaan karakter yang paling menentukan antara ikan nila jantan dan ikan nila betina yang mengindikasikan terdapatnya perbedaan karakter morfologi antara ikan jantan dan ikan betina uji. Karakter morfologi seperti ini mempunyai kesamaan dengan udang jari (Metapenaeus elegans) sebagaimana hasil penelitian Hidayat (2007) bahwa pada udang jari (Metapenaeus elegans) bentuk tubuh udang jantan berbeda dengan bentuk tubuh udang betina, hal ini ditunjukkan dengan adanya perbedaan nilai matrik korelasi baik yang tertinggi maupun yang terendah pada karakter morfologis.

Jarak genetik terkecil terdapat antara famili GIFT 10 dengan famili GET $18 \mathrm{~A}$ dengan nilai 0,001 ; sedangkan jarak genetik terbesar adalah antara famili GET 09C dengan famili GET $18 \mathrm{C}$ dengan nilai 0,026 . Untuk lebih jelasnya dapat dilihat pada nilai jarak genetik antara 9 famili ikan nila uji betina dan jantan (Tabel 6).

Berdasarkan kluster dendrogram jarak genetik dari 9 famili ikan nila uji pada tingkat kemiripan $70 \%$ dikelompokkan kedalam 3 kelompok, yakni kelompok 1 adalah famili GET 18A, GIFT 10, GET 18B, GIFT 04; kelompok 2 adalah famili GET 09B, GET 04B, GET 23; dan kelompok 3 adalah famili GET 18 C dan famili GET 09C. Dendrogram tersebut menjelaskan bahwa hubungan kekerabatan antara

Tabel 6. Nilai jarak genetik sembilan famili ikan nila uji (betina dan jantan)

Table 6. Genetic distance between nine families of nile tilapia (female dan male)

\begin{tabular}{llllllllll}
\hline \multicolumn{1}{c}{ Famili } & GET & GET & GET & GET & GET & GET & GET & GIFT & GIFT \\
Families & 18A & 18C & 18B & 09B & 09C & 04B & 23 & $\mathbf{4}$ & $\mathbf{1 0}$ \\
\hline GET 18A & & & & & & & & & \\
GET 18C & 0.007 & & & & & & & & \\
GET 18B & 0.001 & 0.008 & & & & & & & \\
GET 09B & 0.002 & 0.005 & 0.003 & & & & & & \\
GET 09C & 0.018 & 0.026 & 0.019 & 0.020 & & & & & \\
GET 04B & 0.002 & 0.004 & 0.002 & 0.001 & 0.017 & & & & \\
GET 23 & 0.003 & 0.006 & 0.002 & 0.001 & 0.020 & 0.002 & & & \\
GIFT 04 & 0.004 & 0.011 & 0.002 & 0.004 & 0.024 & 0.005 & 0.003 & & \\
GIFT 10 & 0.000 & 0.008 & 0.001 & 0.003 & 0.018 & 0.002 & 0.004 & 0.004 & \\
\hline
\end{tabular}

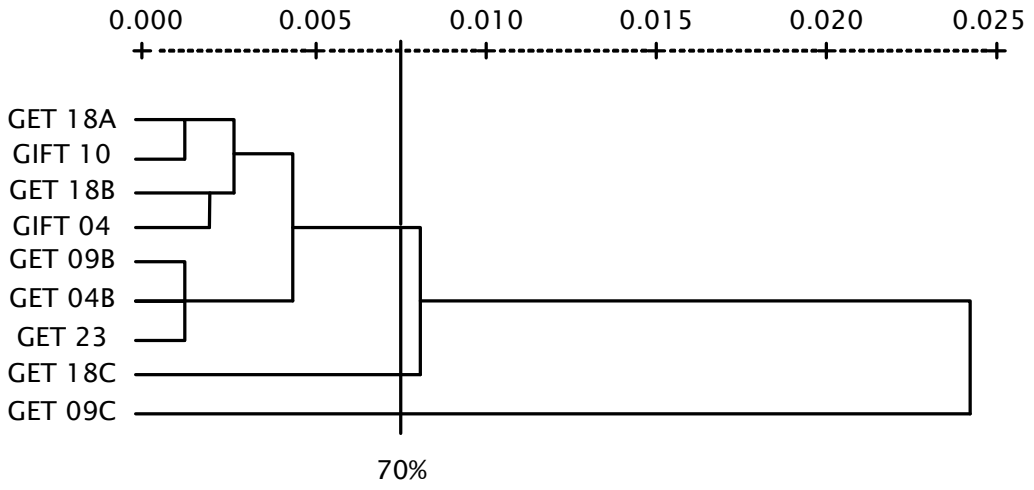

Gambar 3. Dendrogram jarak genetik 9 famili ikan nila betina dan jantan berdasarkan hasil analisis hirarki kluster

Figure 3. Genetic distance cluster dendrogram between nine families female and maleof nile tilapia 
kelompok 1 dengan kelompok 2 lebih dekat dibandingkan dengan kelompok 1 dengan kelompok 3 atau kelompok 2 dengan kelompok 3. Kelompok 3 terutama famili GET 09C adalah famili tersendiri dan terpisah dari famili lainnya, karena mempunyai jarak genetik yang berjauhan dengan 8 famili lainnya (Gambar 3).

Berdasarkan dendrogram tersebut, mengindikasikan bahwa famili yang digunakan merupakan kelompok populasi yang mempunyai kekerabatan yang sangat erat dan berasal dari yang mempunyai karakter genetik dekat. Seperti diketahui bahwa ke-9 famili yang digunakan merupakan ikan hasil seleksi dari 8 populasi pembentuk yang mempunyai jarak genetik berdekatan. Sehingga hasil persilangan antara populasi yang digunakan, dalam kondisi normal akan menghasilkan keturunan yang tidak jauh berbeda dengan populasi pembentuknya. Eknath (1991) mengemukakan bahwa dari 8 populasi yang digunakan dalam program seleksi untuk menghasilkan ikan nila GIFT, 7 populasi mempunyai jarak genetik yang berdekatan, kecuali populasi yang berasal dari Kenya yang mempunyai jarak genetik yang cukup berjauhan dengan ketujuh populasi lainnya.

Ikan nila yang diamati merupakan ikan budi daya hasil program seleksi, sehingga faktor yang mempengaruhi hubungan kekerabatan diduga merupakan hasil dari perbedaan sumber induk yang digunakan, karena lingkungan perairan dianggap homogen antara populasi yang satu dengan lainnya. Menurut Koh et al., (1999), semakin kecil jarak genetik antar individu dalam satu populasi, maka semakin seragam populasi tersebut. Tingkat kemiripan genetik dari suatu populasi dapat digambarkan oleh jarak genetik dari individuindividu anggota populasi. Semakin besar jarak genetik individu di dalam suatu populasi, maka populasi tersebut memiliki anggota yang semakin beragam (Pandin, 2000).

\section{KESIMPULAN DAN SARAN}

Terdapat delapan karakter yang dapat dipakai dalam membedakan sembilan famili ikan nila uji, yaitu B4, C5, A6, C3, A2, A3, B1, dan C6. Nilai kesamaan ukuran tubuh dalam famili tertinggi diperoleh pada famili GET 18C dan terendah pada famili GET 09C dan GET 18A. Keseluruhan ikan uji mempunyai kekerabatan yang erat, kecuali pada famili GET 09C. Hal ini terlihat dari adanya daerah himpitan antar famili dan kedekatan jarak genetik antar famili.
Untuk melengkapi dan memperoleh data karakter yang lebih lengkap, sebaiknya dilakukan juga penelitian mengenai karakter secara genotif.

\section{DAFTAR FUSTAKA.}

Brojo, M. 1999. Ciri-ciri morfometrik ikan nila strain Chitralada dan strain GIFT. Jurnal Ilmu-IImu Perairan dan Perikanan Indonesia. $\mathrm{VI}(2): 21-38$.

Blezinsky, V.J. and R.W. Doyle. 1988. A morphometrics criterion for sex discrimination in tilapia. In R.S.V. Pullin, T. Bhukaswan, K. Tonguthai and J.L. Maclan. (Eds). The Second International Symposium on Tilapia in Aquaculture. ICLARM Conference Proceeding. Department of Fisheries, Bangkok, Thailand, and ICKARM, Manila, Philiphines. 15: 439-444.

Eknath, A.E., J.M. Macaranas, L.Q. Agustin, R.R. Velasco, M.C.A. Ablan, M.J.R. Pante, and R.S.V. Pullin. 1991. Biochemical and morphometric approaches to characterize farmed tilapias. Naga. The ICLARM Q. 14(2): 7-9.

Hidayat. 2007. Keragaman Fenotip Populasi Udang Jari (Metapenaeus Elegans) Berdasarkan Karakter Morfometrik dan Meristik di Laguna Segara Anakan Cilacap Jawa Tengah. Skripsi. Institut Pertanian Bogor. $52 \mathrm{pp}$.

Imron. 1997. Keragaman Morfologis dan Biokimiawi Beberapa Stok Keturunan Induk Udang Windu (Penaeus monodon) Asal Laut yang Dibudidayakan di Tambak. Tesis, Program Pasca Sarjana, Institut Pertanian Bogor. 69 pp.

Imron, O.Z. Arifin, dan Subagyo. 2000. Karakterisasi Truss Morfometrik pada Ikan Mas (Cyprinus carpio) Galur Majalaya, Rajadanu Tildan dan Sutisna. Prosiding Seminar Hasil Penelitian Perikanan 1999/ 2000. Puslitbang Eksplorasi Laut dan Perikanan. Departemen Eksplorasi Laut dan Perikanan. Jakarta. p. 188-197.

Karson, M.J. 1982. Multivariate Statistical Methods: An Introduction. The lowa State University Press. lowa. 307 pp.

Li Sifa. 1997. Dissemination and Evaluation of Genetically Improved Tilapia Species in Asia in China. Shanghai Fisheries University. $114 \mathrm{pp}$.

Koh, T.L., G. Khoo, Li Qun Fan, and V.P.E. Phang. 1999. Genetic Diversity Among Wild Forms and Cultivated Varieties of Discus 
(Symphysodon spp.) as Revealed by Random Amplified Polymorphic DNA (RAPD) Fingerprinting. Aquaculture. 173: 485-497

Nei, M. and F. Tajima. 1981. DNA polymorphism detectable by restriction endonucleases. Genetics. 97: 146-163.

Pandin, D.S. 2000. Kemiripan Genetik Populasi Kelapa dalam Mapanget Tenga, Bali, Palu dan Sawarna Berdasarkan Penanda RAPD. Tesis. Program Pasca Sarjana IPB. Bogor. 45 pp.

Rahmawati, R. 1999. Karakter Fenotipik dan Potensi Tumbuh Ikan Gurame, Osphronemus gouramy, Lacepede. Tesis. Bogor: Program Pasca Sarjana, Institut Pertanian Bogor. 48 pp.
Suparyanto, A.,T. Purwadaria, dan Subandriyo. 1999. Pendugaan jarak genetik dan faktor peubah pembeda bangsa dan kelompok domba di Indonesia melalui pendekatan analisis morfologi. Jurnal Ilmu Ternak dan Veteriner. 4: 80-87.

Vellasco, R.R, M.J.R. Pante, J.M. Macaranas, C.C. Janagap, and A.E. Eknath. 1996. Truss morphometric characterization of eight strains of Nile Tilapia (Oreochromis niloticus). p. 415-425. In. R.S.V. Pullin, J. Lazard, M. Legendre, J.B. Amon Kothias, and D. Pauly (Eds.). The Third International Symposium on Tilapia in Aquaculture. ICLARM Conf. Proc. 41. 